\title{
New Fossil Reptile Records from the Siwalik of North India
}

\author{
A. C. Nanda1, H. H. Schleich², B. S. Kotlia ${ }^{3 *}$ \\ ${ }^{1}$ Wadia Institute of Himalayan Geology, Dehradun, India \\ ${ }^{2}$ Fuhlrott Museum \& Research Institute, Wuppertal, Germany \\ ${ }^{3}$ Centre of Advanced Study in Geology, Kumaun University, Nainital, India \\ Email: nandaac@rediffmail.com, 'bahadur.kotlia@gmail.com
}

Received 18 April 2016; accepted 2 August 2016; published 5 August 2016

Copyright (C) 2016 by authors and Scientific Research Publishing Inc.

This work is licensed under the Creative Commons Attribution International License (CC BY).

http://creativecommons.org/licenses/by/4.0/

(c) (i) Open Access

\section{Abstract}

From the Siwalik Group of Haryana and Himachal Pradesh, new fossil reptile records are described. The Siwalik fauna from Haryana and Himachal is recorded from the pre-Pinjor and Pinjor beds (Upper Siwalik Subgroup: Pliocene-Lower Pleistocene). The reptile fauna includes Crocodylus aff. palustris, Gavialis cf. gangeticus, Rhamphosuchus crassidens, Batagur sp., Geoclemys hamiltoni and Hardella thurjii. The findings are significant as fossil reptiles from the Siwalik Group are scanty as compared to the richer mammalian fauna.

\section{Keywords}

Fossils, Reptile, Pinjor Formation, Siwalik, Pliocene-Pleistocene, North India

\section{Introduction}

The Siwalik belt forms the southern most foothills of the Himalaya and except for a small gap near Sikkim it extends from the Indus River in the west to the Brahmaputra River in east. The Siwalik Group is well known for its richness in vertebrate fossils and ranges from $18.3 \mathrm{Ma} 8$ [1] to $0.22 \mathrm{Ma}$ [2]. In the early Miocene, a tectonic depression was formed in front of the rising Himalaya and in this depression fresh water molasse sediments were deposited. These contain terrestrial sediments, which comprise mudstones/siltstones, sandstones and conglomerates with gross lithology becoming coarser in the younger horizons.

Although the Siwalik Group is known for its richness in mammalian fauna, but comparatively scanty fossil reptile material has been described in the past since the time of Cautley [3] [4], more detailed systematic palaeontology studies followed by Lydekker [5]-[7]. Most recent listings of fossil reptiles from the Siwalik are re-

${ }^{*}$ Corresponding author. 
ported a number of workers [8]-[13] with the subsequent revisions [14]. Above studies allow to list the following genera: Crocodylus, Gavialis, Rhamphosuchus, Colossochelys, Batagur, Callagur, Geoclemys, Kachuga, Aspideretes, Chitra and Lissemys. Acrochordus dehmi is the only snake described from the Siwalik so far. In present contribution, new fossil reptilian material, which is collected by one of us (ACN), is described here.

\section{Geology and Stratigraphy of the Area}

The new reptile collection originates from the Upper Siwalik Subgroup of northwestern Himalaya exposed in between the Ghaggar and Yamuna rivers (i.e. the area between Chandigarh and Paonta). This Upper Siwalik collection belongs to two areas one from east of Panchkula and the other one from Haripur area, west of Paonta. A location map showing the Upper Siwalik collection area is presented in Figure 1. Until recently most researchers paid attention mainly to the systematic descriptions of the mammalian material and based their stratigraphic interpretations on those fossils. The present description of the reptile material with the various details regarding the stratification and associated mammalian fauna are briefed below.

\section{Upper Siwalik Succession of Panchkula and Paonta Areas}

East of the twin cities of Chandigarh and Panchkula, the Upper Siwalik Subgroup forms a continuous fossiliferous belt. Vertebrate collections were made from two pockets. The area east of Panchkula is richly fossiliferous,

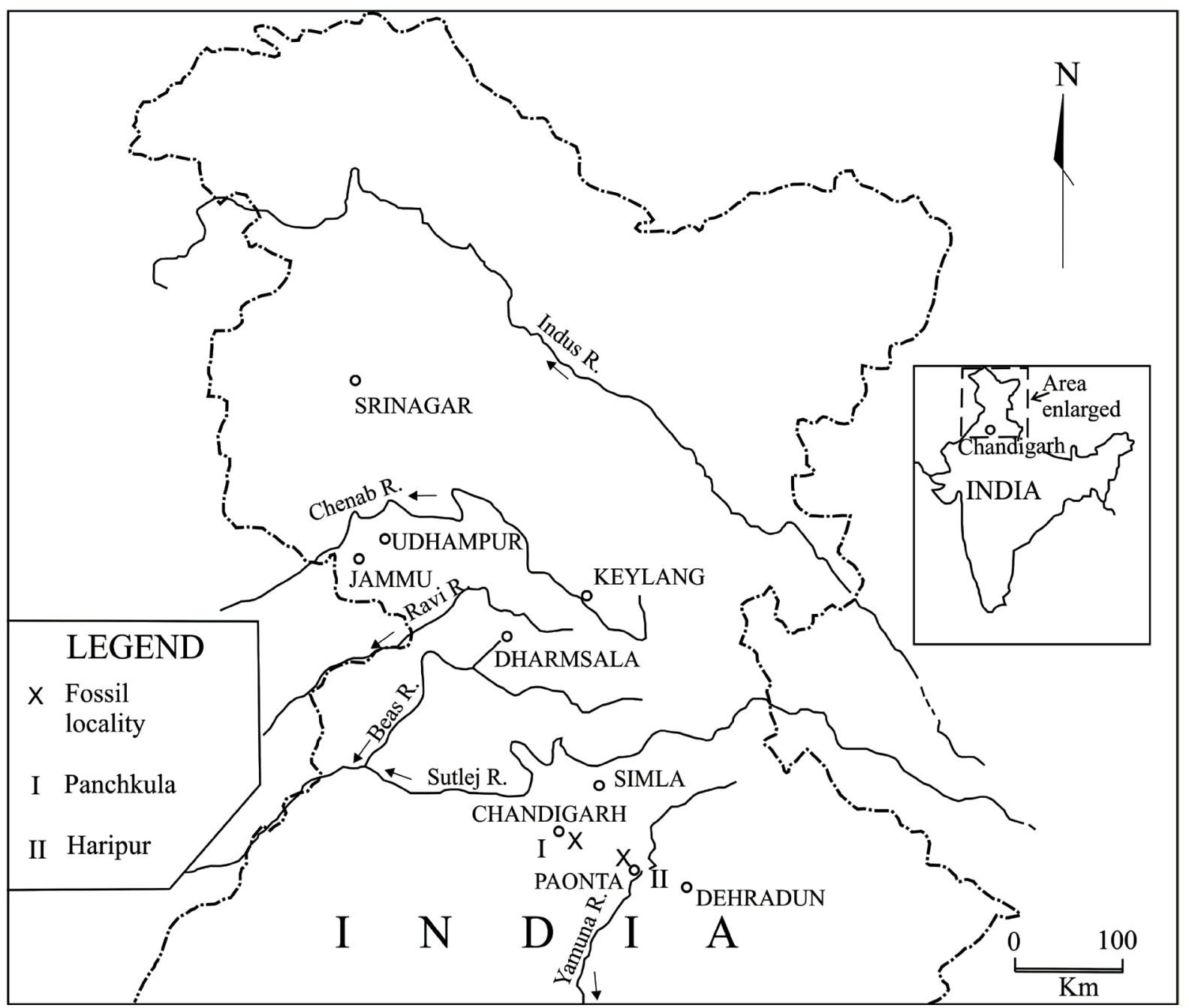

Figure 1. Map showing localities with fossil reptile material. I and II marked in the map yielded significant fossil reptiles. A geological map of I and II is given in Figure 2 and Figure 3, respectively. 
whereas the area west of Paonta is scanty fossiliferous area. The various details are discussed below.

\subsection{Upper Siwalik Succession, East of Panchkula Area}

This area forms the type area for the Pinjor Formation and the township of Pinjore (Pinjor or Pinjaur) lies about $6 \mathrm{~km}$ from Panchkula. Sahni and Khan [15] recognized for the first time the pre-Pinjor beds (they called these as belonging to "Tatrot Stage") from the area immediately east of Chandigarh. However, these beds were referred to as the Dhamala Formation [16] [17]. As the type area of the Tatrot Formation lies $400 \mathrm{~km}$ west of this place, Nanda [18] [19] referred these to the pre-Pinjor beds till future consensus for the nomenclature of these beds. However, these rocks were further described as Saketi Formation in the Saketi area of Himachal Pradesh [20]. Thus, there remains confusion in the nomenclature to be applied. Near Saketi village a full succession of these beds is well exposed, so these (pre-Pinjor beds) may be referred as Saketi Formation [20]-[22]. However, till general acceptance of the nomenclature, pre-Pinjor beds convey the stratigraphic position of the beds within the Upper Siwalik Subgroup. These pre-Pinjor beds (=Saketi Formation, =Tatrot Formation, =Dhamala Formation), the basal beds of the Upper Siwalik succession, were included by earlier authors in the Pinjor formation, although the Tatrot fossils were known to them but lacking their exact locations [23] [24]. Initially, these beds were distinguished on the basis of lithology and mammalian fauna [15]. The Upper Siwalik succession in this belt may be divided into three formations, representing the pre-Pinjor, the Pinjor and the Boulder Conglomerate beds. Both pre-Pinjor and Pinjor beds are richly fossiliferous.

Lithologically, it is easier to separate the pre-Pinjor beds from the Pinjor beds. Pre-Pinjor beds are dominated by bright grey and variegated mudstones as those of the overlying Pinjor Formation are characterized by dull pink and red mudstones. The lithology along with characteristic fossils are given in Table 1. A more detailed faunal list based on in situ collection of the last five decades is presented in Table 2. The Siwalik biostratigraphy is based on mammalian fossils so far. The Pinjor beds contain about 57 mammalian marker taxa whereas pre-Pinjor beds show only 31 mammalian marker taxa. To these mammalian records now the reptile taxa can be mentioned for this contemporary vertebrate coenosis. These reptile taxa, being described here, are also included in Table 2. A geological map of the area showing localities yielding reptile material is given in Figure 2. The base of the pre-Pinjor beds at Saketi area was dated as 3.15 Ma [17], 5.26 Ma in nearby Haripur area [25], whereas the Tatrot Pinjor contact (i.e. the top of the Saketi beds) coincides with the Gauss-Matuyama break i.e. at $2.48 \mathrm{Ma}$ (later placed at 2.58 Ma [26]. The base of the Boulder Conglomerate is found to be time transgressive and ranges from 0.63 Ma to 1.79 Ma in the area lying east of Chandigarh-Panchkula [27].

\subsection{Upper Siwalik Succession of Haripur Area, West of Paonta}

The second thrust area from which new reptile material was collected lies in the vicinity of Haripur village, west of Yamuna River. A geological map of the area is provided as Figure 3. This area lies in strike continuation of

Table 1. Succession of the upper siwalik subgroup in the area between Panchkula and Haripur.

\begin{tabular}{|c|c|c|}
\hline Formation (with age) & Lithology & Marker Taxa \\
\hline $\begin{array}{l}\text { Boulder Conglomerate } \\
{ }^{*} 0.63 \text { to } 1.79 \mathrm{Ma}\end{array}$ & $\begin{array}{l}\text { Boulders, cobbles, pebbles mainly of grey and purple coloured, } \\
\text { rounded to well-rounded compact sandstones; set in matrix of } \\
\text { coarse to very coarse occasional gravel matrix. Sometimes } \\
\text { coarse sandstone, siltstone, mudstone beds or lenses are present. } \\
\text { Clasts of limestone are present but very less. }\end{array}$ & No fossils \\
\hline Pinjor $2.60 \mathrm{Ma}$ & $\begin{array}{l}\text { Alternation of dull, brown, pink mudstones and coarse to } \\
\text { medium-grained, grey, green, pebbly and soft sandstones. } \\
\text { Sometimes in the upper part sandstone beds alternate with } \\
\text { conglomeratic (pebbly sized) beds. }\end{array}$ & $\begin{array}{c}{ }^{* *} \text { First appearance of Equus, } \\
\text { Cervus (cervids with antlers), } \\
\text { Bubalus, Bos etc. }\end{array}$ \\
\hline $\begin{array}{l}\text { Pre-Pinjor beds (=Tatrot Stage, } \\
=\text { Dhamala Formation, =Saketi } \\
\text { Formation of various workers) } \\
{ }^{* * *} 5.26 \mathrm{Ma}\end{array}$ & $\begin{array}{l}\text { Bright grey and variegated mudstones interbedded with grey, } \\
\text { brown coarse to medium-grained soft sandstones. }\end{array}$ & $\begin{array}{l}{ }^{* *} \text { Hipparion, Cormohipparion, } \\
\text { Stegodon bombifrons, } \\
\text { Hippohyus lydekkeri } \\
\text { (=H. tatroti) etc. }\end{array}$ \\
\hline
\end{tabular}

${ }^{*}$ Contact between the Pinjor and Boulder Conglomerate Formations is time transgressive. Ages are taken after Ranga Rao et al. [32] and Kumaravel et al. [33]. ${ }^{* *}$ See complete list in Table 2. ${ }^{* * *}$ After Sangode et al. [25], otherwise marked by Azzaroli and Napoleone [17] at 3.15 Ma in Saketi area. 
Table 2. Distribution of various reptilian and mammalian genera/species in the Pinjor and pre-Pinjor beds (=Tatrot beds, =Saketi beds, =Dhamala beds) of the Upper Siwalik Subgroup of Chandigarh region (based on collection of last five decades by the first author [21] [22].

\begin{tabular}{|c|c|}
\hline Class Reptilia & \\
\hline CROCODYLIA: & Crocodylus aff. palustris", Gavialis cf. gangeticus, Rhamphosuchus crassidens* \\
\hline TESTUDINES: & Batagur sp ${ }^{* *}$, Geoclemys hamiltoni, Hardella cf. thrurjii ${ }^{*}$ \\
\hline \multicolumn{2}{|l|}{ Class Mammalia } \\
\hline \multicolumn{2}{|l|}{ Pinjor beds } \\
\hline LIPOTYPHLA & (=INSECTIVORA): Chandisorex punchkulaensis \\
\hline PRIMATES: & Procynocephalus pinjorii,? Homo erectus, Theropithecus delsoni \\
\hline LAGOMORPHA: & Caprolagus sivalensis \\
\hline RODENTIA: & $\begin{array}{l}\text { Nesokia punchkulaensis, Rattus sp., Hystrix leucurus, Mus linnaeusi, M. cf. M. flynni, Cremnomys cf. C. } \\
\text { blanfordi, Golunda sp., Dilatomys sp., Hadromys loujacobsi, Tatera pinjoricus, Anepsirhizomys pinjoricus } \\
\text { (=“Rhizomys” pinjoricus), Bandicota sp. }\end{array}$ \\
\hline CARNIVORA: & $\begin{array}{l}\text { Canis pinjorensis, } \text { Mellivora sivalensis, } \text { Pachycrocuta brevirostris (=Crocuta felina, }=C \text {. sivalensis, }=C \text {. } \\
\text { colvini), Panthera cf. } \text { P. cristata, Hyaenictis bosei, Megantereon palaeindicus, Sivapanthera }(=\text { Sivafelis) } \\
\text { potens, Enhydriodon sivalensis, Lutra palaeindica, Amblonyx indicus }\end{array}$ \\
\hline PROBOSCIDEA: & Stegodon pinjorensis, Elephas hysudricus, E. platycephalus \\
\hline PERISSODACTYLA: & $\begin{array}{l}\text { Equus sivalensis, ? E. namadicus, Coelodonta platyrhinus (=Punjabitherium platyrhinus), Rhinoceros } \\
\text { palaeindicus, } \text { R. sivalensis }\end{array}$ \\
\hline ARTIODACTYLA: & $\begin{array}{l}\text { Potamochoerus theobaldi, Sus falconeri, S. hysudricus, S. giganteus, S. choprai, Cervus. punjabiensis, C. } \\
\text { sivalensis, Sivatherium giganteum, Sivacapra subhimalayaensis, Damalops palaeindicus, Oryx sivalensis, } \\
\text { Sivacobus palaeindicus, Antilope subtorta, Vishnucobus (=Indoredunca) sterilis, Hemibos acuticornis, H. } \\
\text { triquetricornis, H. antelopinus, Bubalus bubalis var. palaeindicus, B. platyceros, Leptobos falconeri, Bison } \\
\text { sivalensis, Bos acutifrons }\end{array}$ \\
\hline $\begin{array}{l}\text { Extend from the } \\
\text { pre-Pinjor beds }\end{array}$ & $\begin{array}{l}\text { Golunda kelleri, Crocidura sp., Protocyon (=Sivacyon) curviplatus, Anancus (=Pentalophodon) sivalensis, } \\
\text { Elephas planifrons, Stegolophodon stegodontoides, Stegodon insignis, S. katliensis, ? Chilotherium } \\
\text { intermedium, Potamochoerus palaeindicus, Hippohyus sivalensis, Hexaprotodon sivalensis, Cervus cf. C. } \\
\text { triplidens, Camelus sivalensis, Gazella cf. G. lydekkeri,? Gazella sp. }\end{array}$ \\
\hline \multicolumn{2}{|l|}{ Pre-Pinjor beds } \\
\hline LIPOTYPHLA & (=INSECTIVORA): Suncus cf. S. murinus \\
\hline LAGOMORPHA: & Pliosiwalagus whitei \\
\hline RODENTIA: & $\begin{array}{l}\text { Palaeomys sp., Miorhizomys (= Brachyrhizomys) pilgrimi, Rhizomyides (=Brachyrhizomys) punjabiensis, } \\
\text { Rhizomyides cf. } R \text {. sivalensis, } R \text {. saketiensis, Mus flynni, M. jacobsi, Parapelomys robertsi, Hadromys } \\
\text { primitivus, H. moginandensis, Cremnomys cf. C. cutchicus, Bandicota sivalensis, Protatera cf. P. kabulense, } \\
\text { Golunda tatroticus, Dilatomys moginandensis, Abudhabia cf. A. kabulense }\end{array}$ \\
\hline CARNIVORA: & Saketoteron tatroinse \\
\hline PROBOSCIDEA: & Anancus (=Pentalophodon) khetpuraliensis, Stegodon bombifrons \\
\hline PERISSODACTYLA: & Cormohipparion" (Sivalhippus) theobaldi, ?Hipparion antelopinum \\
\hline ARTIODACTYLA: & $\begin{array}{l}\text { Merycopotamus dissimilis, Hippohyus lydekkeri }(=H . \text { tatroti), Potamochoerus prasadii, Sivachoerus prior, } \\
\text { Hydaspitherium megacephalum, Proamphibos kashmiricus, P. lachrymans, Probison dehmi }\end{array}$ \\
\hline
\end{tabular}

${ }^{*}$ in present collection only from pre-Pinjor beds; ${ }^{* *}$ in present collection only from Pinjor beds.

the area east of Panchkula, but occurrence of vertebrate fossils there is far less. Mudstone intervals dominate in the area east of Panchkula but in the Haripur area sandstone intervals are dominating and with the lessening of those mudstone intervals, finding of vertebrate fossils became scanty. A typical Pinjor Fauna with Equus and Cervus (cervids with antlers) was collected here. However, till date no marker for the pre-Pinjor beds is recorded although the basal part of the Upper Siwalik Subgroup is dominated by grey and variegated mudstones. Even in the Chandigarh-Panchkula area, the Tatrot Fauna is comparatively less developed as compared to the rich Pinjor Fauna. So the absence of any marker fossils for the Tatrot Fauna might be just incidental. Further collections should yield markers for the Tatrot Fauna as well, but the close resemblance of the grey and variegated mud- 
stones succession and strike continuation are indicators of their affinity with the pre-Pinjor beds lying immediately east of Chandigarh-Panchkula. The contact between Pinjor and Boulder Conglomerate Formations at dated as 1.76 Ma [25]. The characteristic lithology of the various horizons is virtually same as mentioned in Table 1. However, pre-Pinjor and Pinjor beds are of more sandy lithology. A detailed list of fossil mammals is given [28] [29] and characteristic Pinjor taxa include Equus, Rhinoceros, Cervus and Bos.

All material being described subsequently is housed in the Museum's collection of Wadia Institute of Himalayan Geology, Dehradun (India). Casts of the material are stored at Fuhlrott Museum \& Forschungsinstitut, Wuppertal. The casts were made by one of the authors (HS) in Dehradun during a field programme (financed by DAAD) in the year 1993. Comparative recent material was kindly made available by Zoologische Staastssammlung München, Germany. Most of the measurements were taken from the casts at Fuhlrott Museum \& Forschungsinstitut and due to shrinkage, minor deviations from the original fossils might occur.

\section{Systematic Palaeontology}

Class: Reptilia Laurenti, 1768

Order: Crocodylia Gmelin, 1788

Family: Crocodylidae Cuvier, 1807

Genus: Crocodylus Laurenti, 1768

Crocodylus aff. palustris

(Plate 1)

Material, locality and horizon: WIF/A 463, fragmented part of cranium; $0.5 \mathrm{~km}$ north of Khetpurali village (Ambala), pre-Pinjor beds (Saketi Formation, =Tatrot Formation).

Description: The fragmented part of a right premaxillary and maxillary is preserved. A deep incision between premaxillary and maxillary is obvious. The dorsal surface is highly pitted. A part of the premaxillary-maxillary

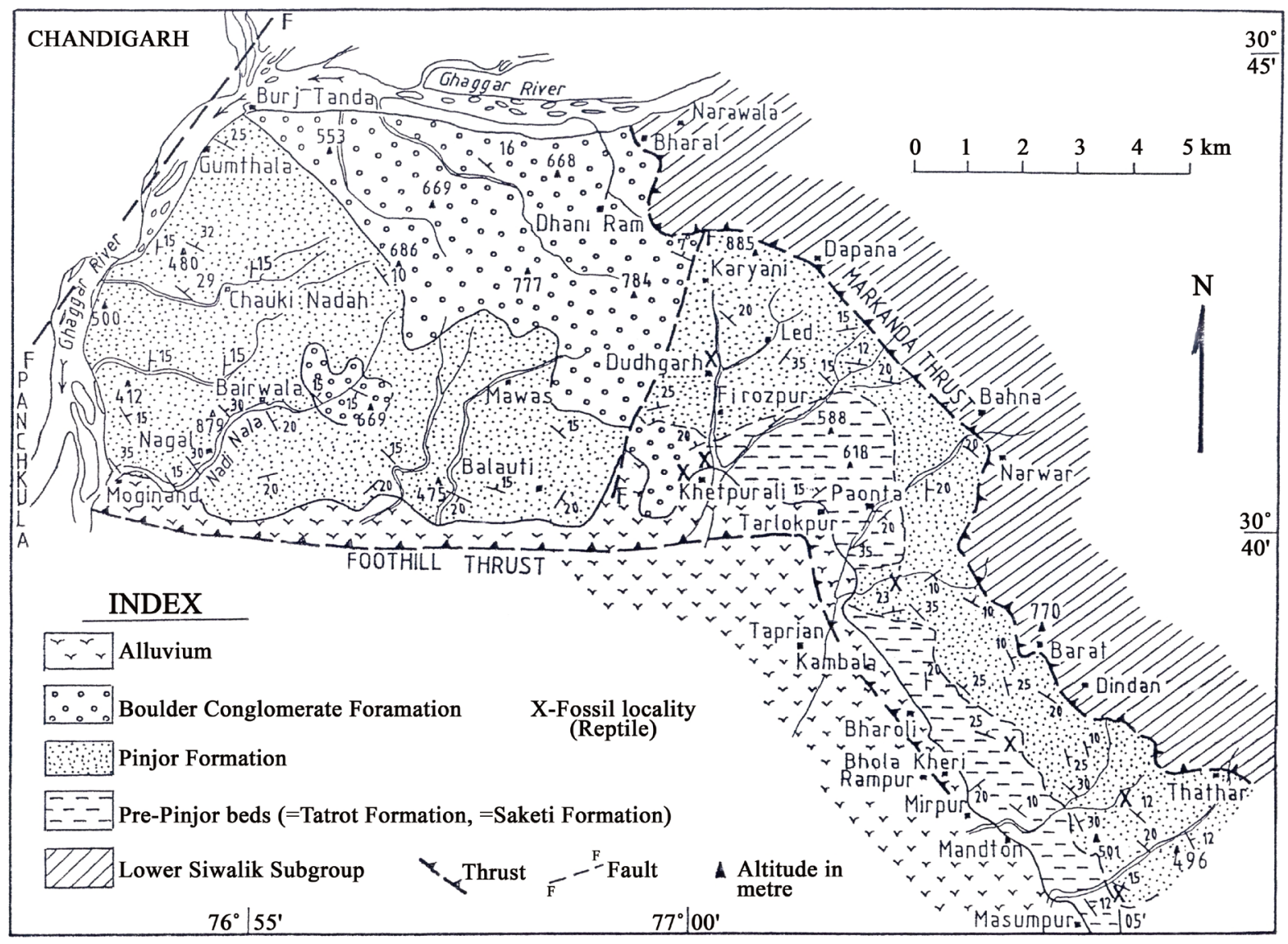

Figure 2. Geological map of the area east of Panchkula and Chandigarh showing localities bearing fossil reptiles. 


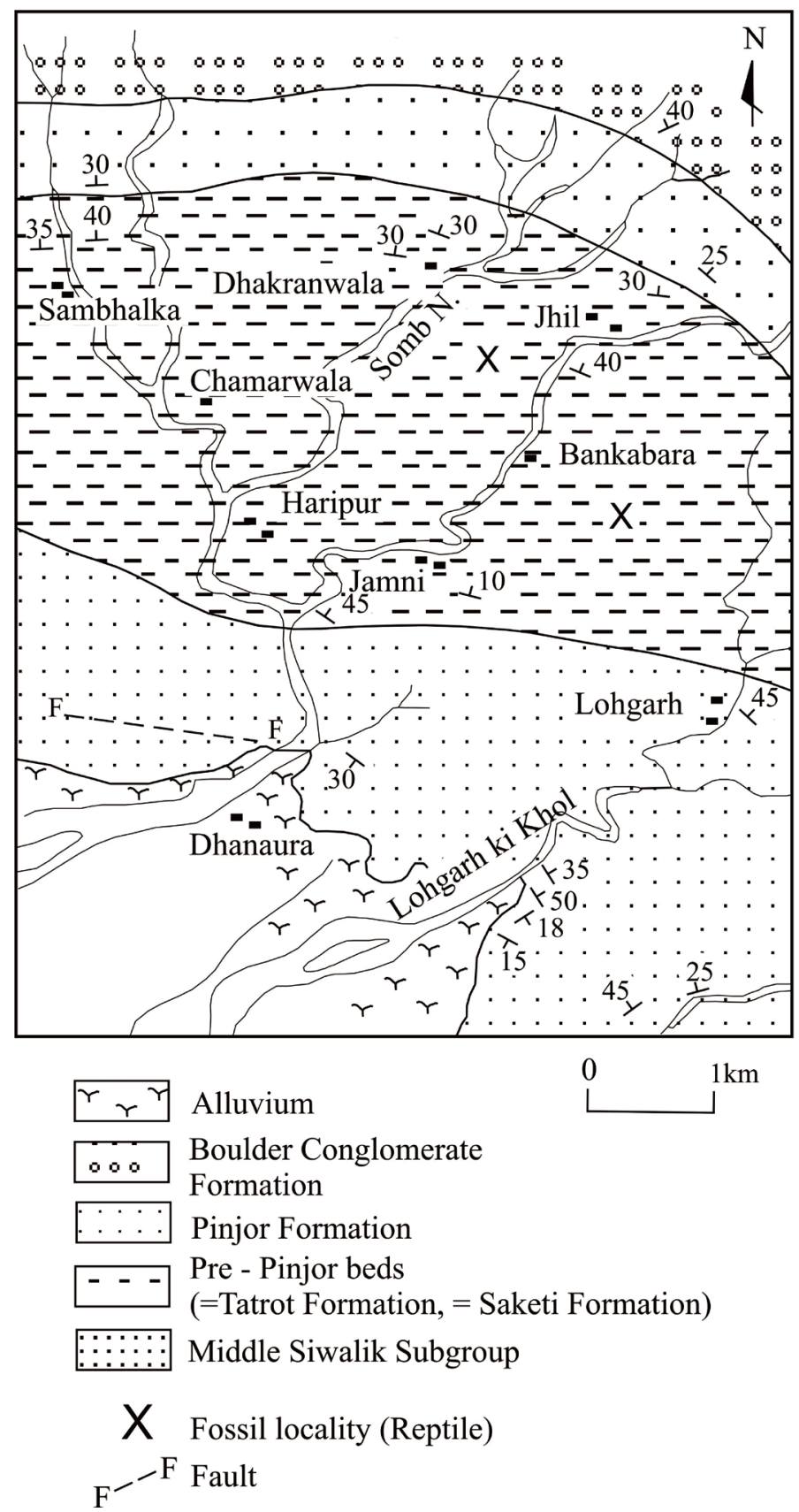

Figure 3. Geological map of Haripur area showing localities with fossil reptile material.

is distinct on its ventral surface. Three alveolies for the premaxillary teeth and seven alveolies for the maxillary teeth are distinctly present; the $5^{\text {th }}$ maxillary tooth is the largest in this series. The alveolies are rounded in shape. The position of premaxillary teeth suggests that there should be five teeth in the row with the $4^{\text {th }}$ being the largest. A tooth fragment is present with the $5^{\text {th }}$ premaxillary tooth. The interdental pits are distinct and are rounded in shape. The interdental distances range between $2-6 \mathrm{~mm}$. The maximum length of the fossil specimen is about $16 \mathrm{~cm}$ and the maximum width at the level of the $5^{\text {th }}$ maxillary teeth measures $6.5 \mathrm{~cm}$.

Family: Gavialidae Adams, 1854

Genus: Gavialis Oppell, 1811

Gavialis cf. gangeticus (Gmelin, 1789)

(Plates 2-4, Plate 5(a), Plate 5(b)) 
Material, locality and horizon: WIF/A 461, fragment of cranium cum maxillary (Plate 2); $2 \mathrm{~km}$ northeast of Taprian Village (Ambala), basal part of the Pinjor Formation.

Description: The preserved part of a left maxillary fragment contains alveolies for ten posterior teeth. The three anterior alveolies are not clearly distinct due to post-mortem crushing of the specimen. The size of the alveolies is almost equal, however, the posterior ones are slightly larger than the anterior ones. The alveolies are mostly rounded in shape; the interalveolar space ranges between $2-6 \mathrm{~mm}$. The width of the nasals is about 2.4 $\mathrm{cm}$. The anterior part of left palatine fenestrae and of the ectopterygoid is preserved. The medial suture is well marked. The maximum length of the preserved specimen is about $17.5 \mathrm{~cm}$ and the maximum width at the anterior end of the palatine fenestrae is about $12.6 \mathrm{~cm}$.

Material, locality and horizon: WIF/A 460, part of upper cranium with posterior part of maxillary (Plate 3); Just north of Khetpurali Scarp (Ambala), pre-Pinjor beds (Saketi Formation, =Tatrot Formation).

Description: The nasals are clearly visible; the width of the nasal bone is about $3.4 \mathrm{~cm}$. Both the orbits are preserved. The diameter (anterio-posterior) of the orbits is approximately $8.2 \mathrm{~cm}$, the space between them is approximately $6.6 \mathrm{~cm}$. The interorbital space is slightly concave and its margins with the orbits are raised. The anterio-posterior diameter of the supratemporal fenestrae is about $6.5 \mathrm{~cm}$. Alveolies for the eight right and six left maxillary teeth are preserved; they are almost of equal diameter and rounded in shape. The interdental space

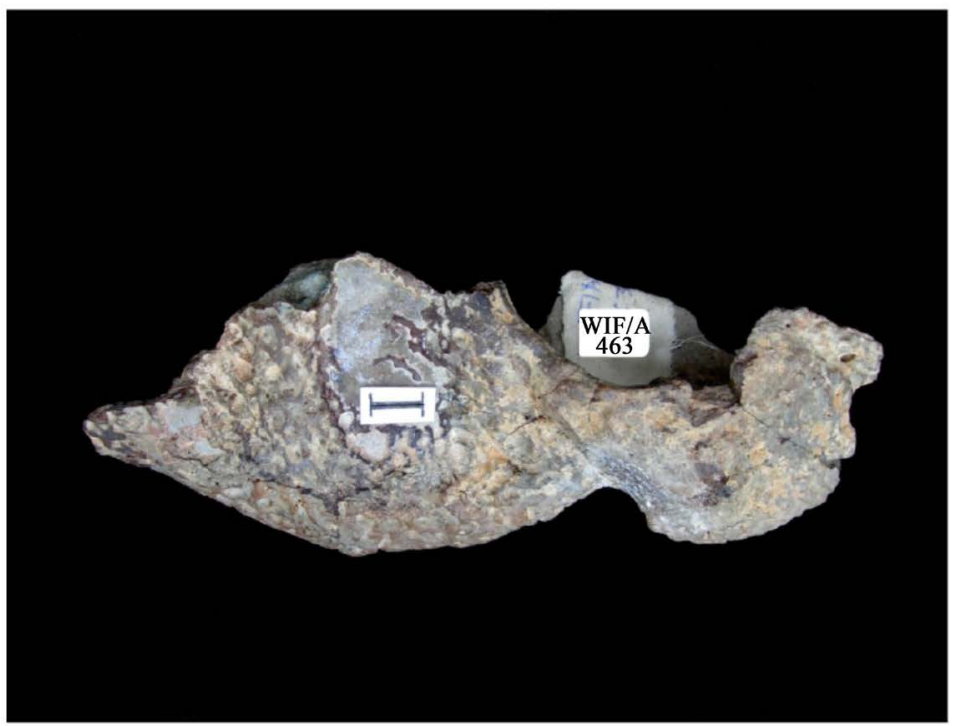

(a)

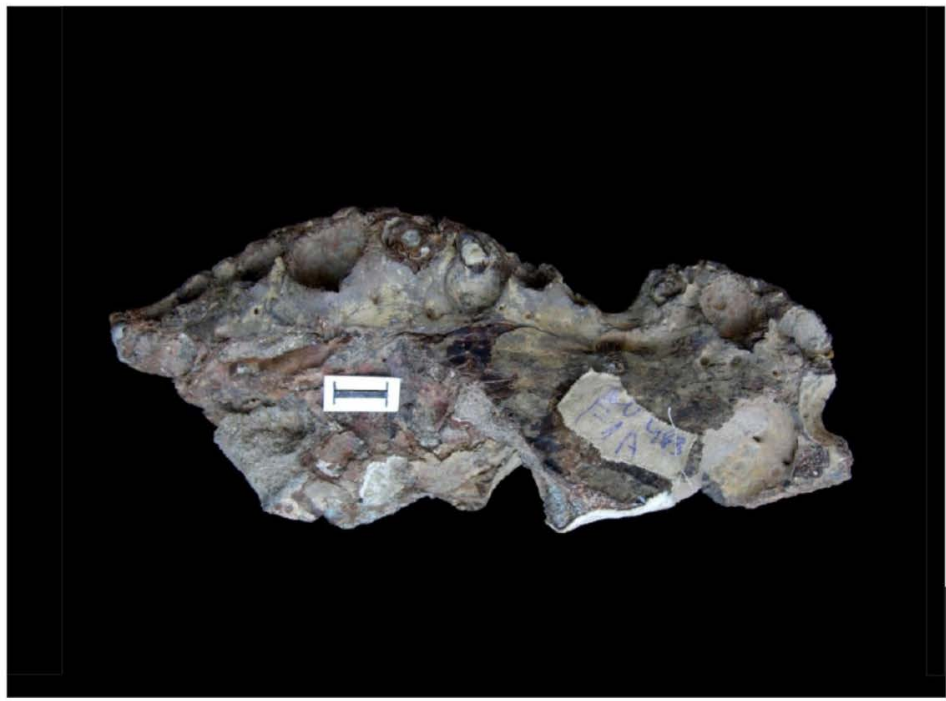

(b)

Plate 1. Crocodylus aff. palustris, fragment of cranium (WIF/A 463), (a) dorsal view, (b) palatinal view. Bar represents $5 \mathrm{~cm}$. 


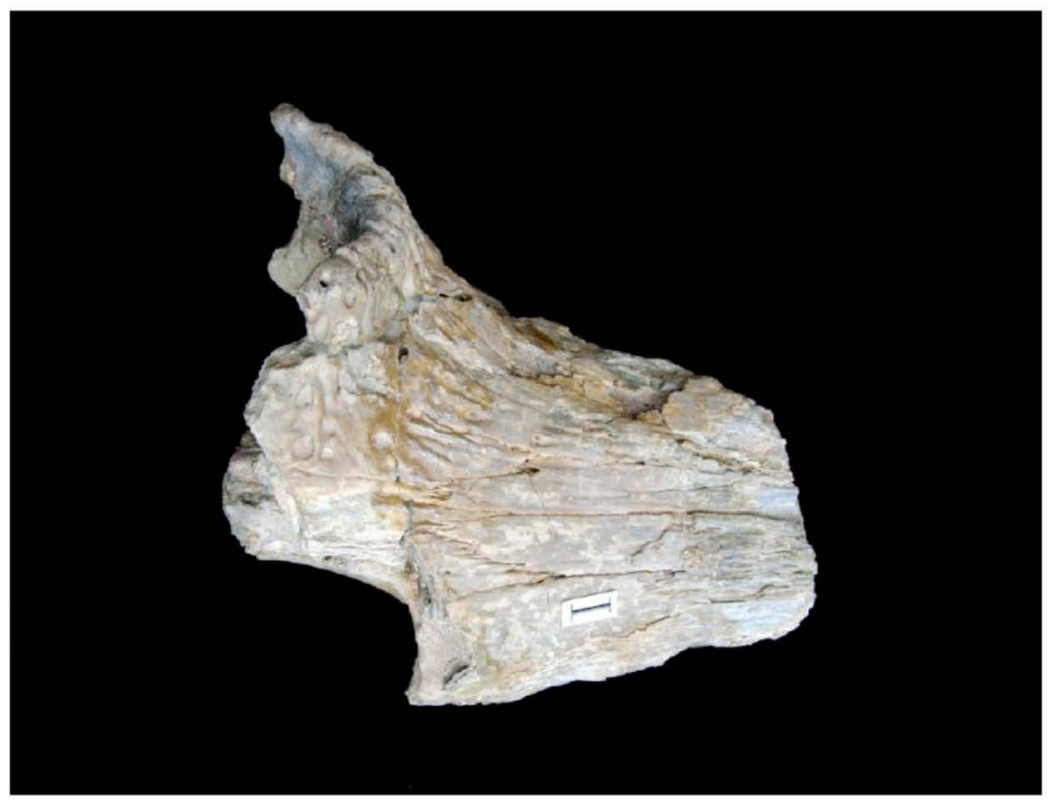

(a)

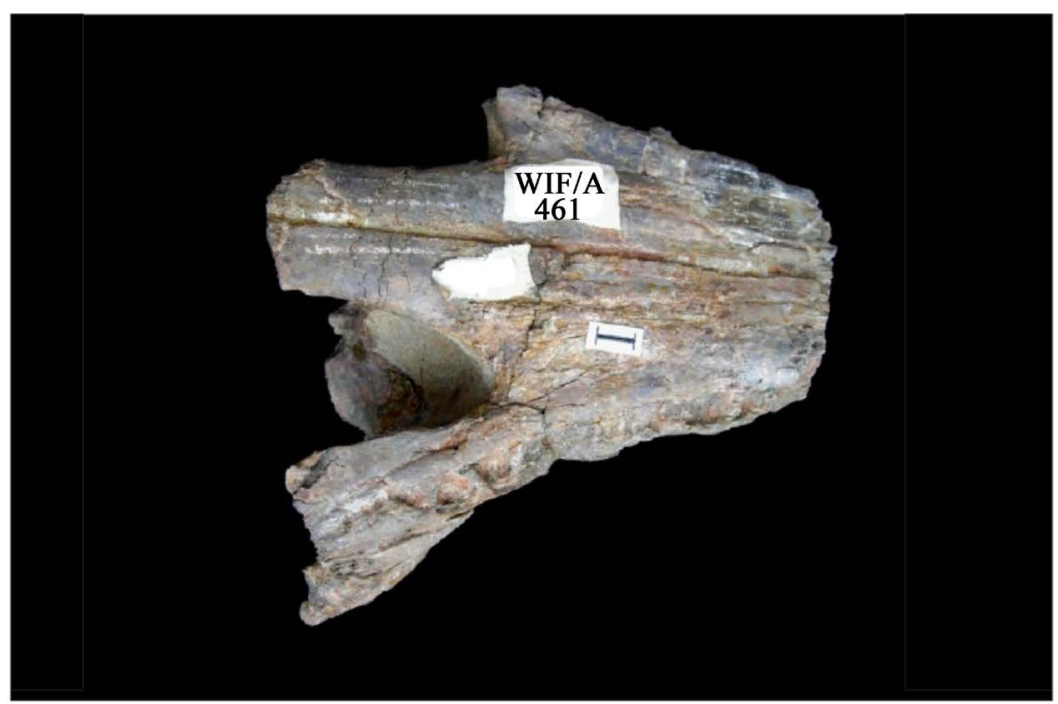

(b)

Plate 2. Gavialis cf. gangeticus, fragment of maxillary portion of cranium (WIF/A 461), (a) Dorsal view, (b) Palatinal view. Bar represents $5 \mathrm{~cm}$.

ranges between $4-10 \mathrm{~mm}$. Palatine fenestrae are oval in shape; the anterio-posterior diameter of the fenestrae is approximately $9.6 \mathrm{~cm}$. The space between the two supratemporal fenestrae measures approximately $4 \mathrm{~cm}$. The inter-orbital space and the space between the two supratemporal fenestrae is highly pitted. The anterior margin of the ectopterygoid reaches up to the last maxillary teeth. The posterior margin of the ectopterygoid reaches almost two-third the length of the pterygoid. The suture between the pterygoid and the palatine and between the ectopterygoid and pterygoid is distinct. The anterio-posterior length of the pterygoid is approximately $7.7 \mathrm{~cm}$.

Material, locality and horizon: WIF/A 459, part of upper cranium (Plate 4); About 2.5 km northeast of Rampur Village (Ambala), Pinjor Formation.

Description: An upper part of cranium is fossilized. The supratemporal fenestrae are well preserved; they are rounded in shape and have a diameter of approximately $4.2 \mathrm{~cm}$; however, the right fenestra is incomplete. Prefrontals are also preserved; the anterior part of the prefrontals is broken. A large basioccipital is distinctly seen. The space between the two supratemporal fenestrae measures approximately $2.3 \mathrm{~cm}$. A foramen magnum is also distinct. The orbits are not preserved but inner margins of orbits and frontal are preserved. The width of the 
frontal between the two orbits is approximately $7.2 \mathrm{~cm}$. The anterio-posterior length of the post-orbital is approximately $3.1 \mathrm{~cm}$. A small posterior part of the palatine is exposed.

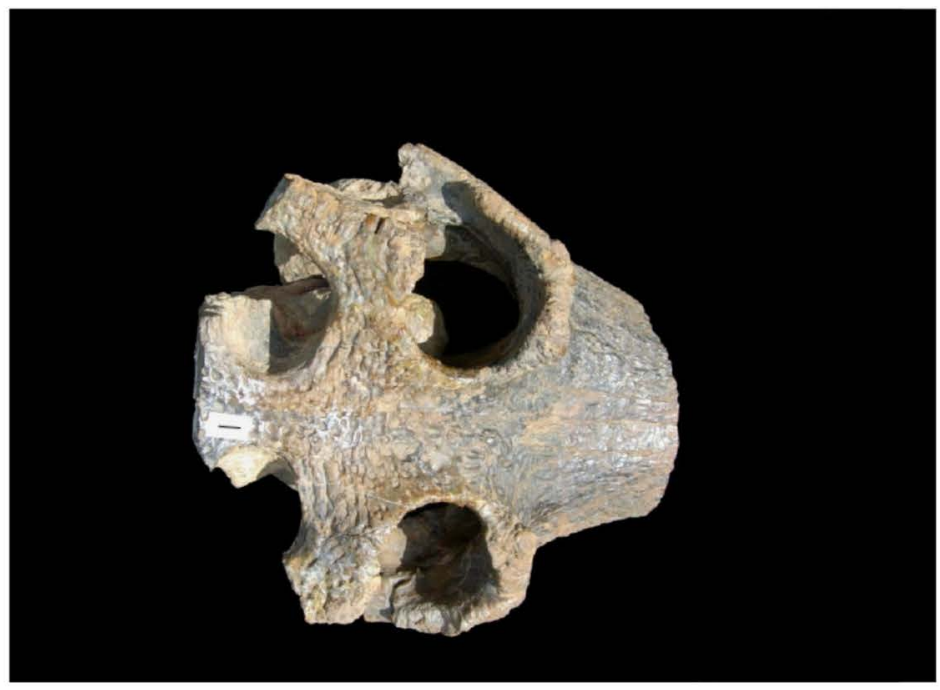

(a)

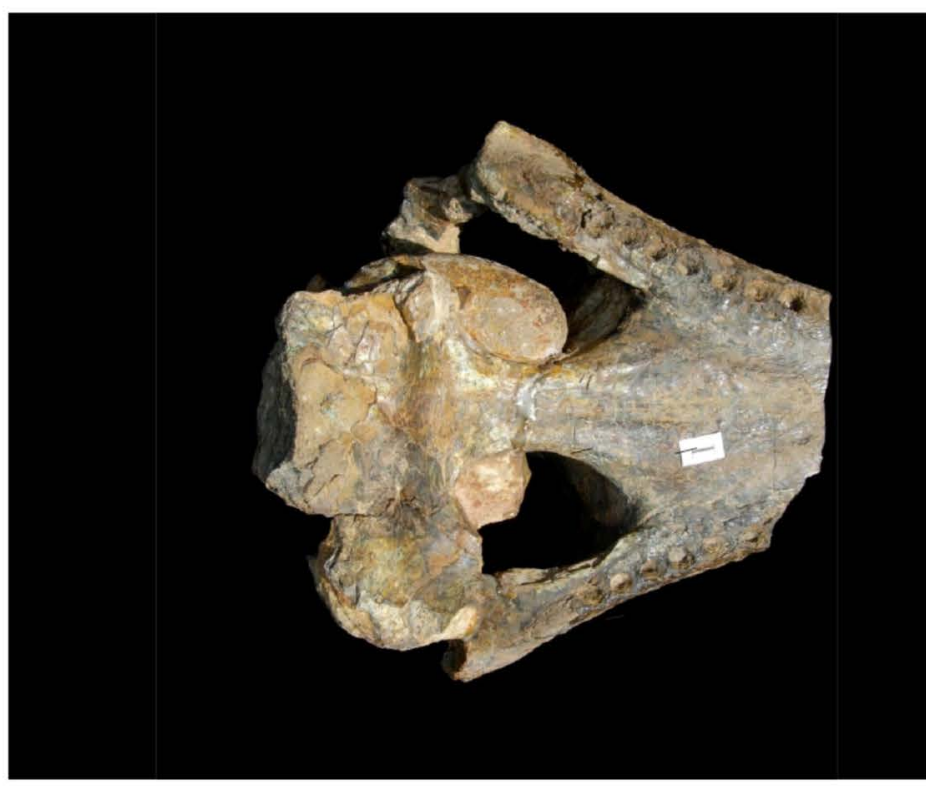

(b)

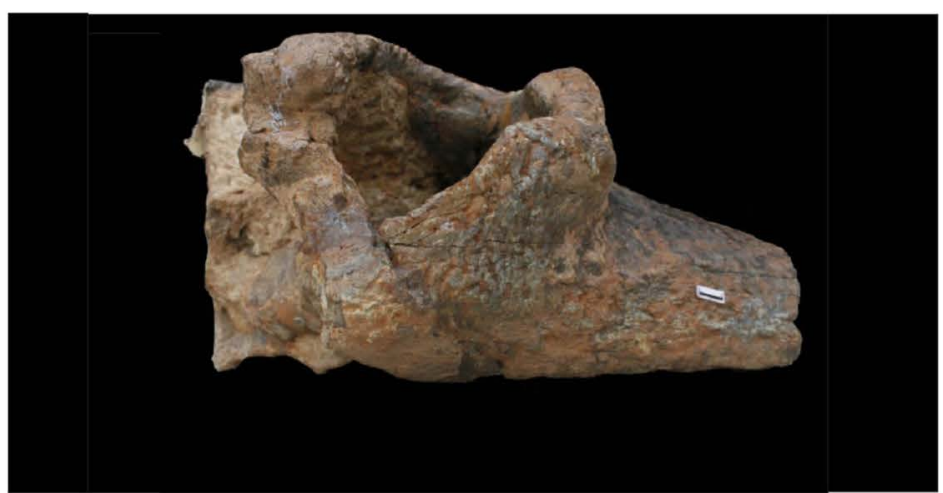

(c)

Plate 3. Gavialis cf. gangeticus, part of upper cranium with posterior part of maxillary (WIF/A 460), (a) Dorsal view, (b) Palatinal view, (c) Right lateral view. Bar represents $5 \mathrm{~cm}$. 

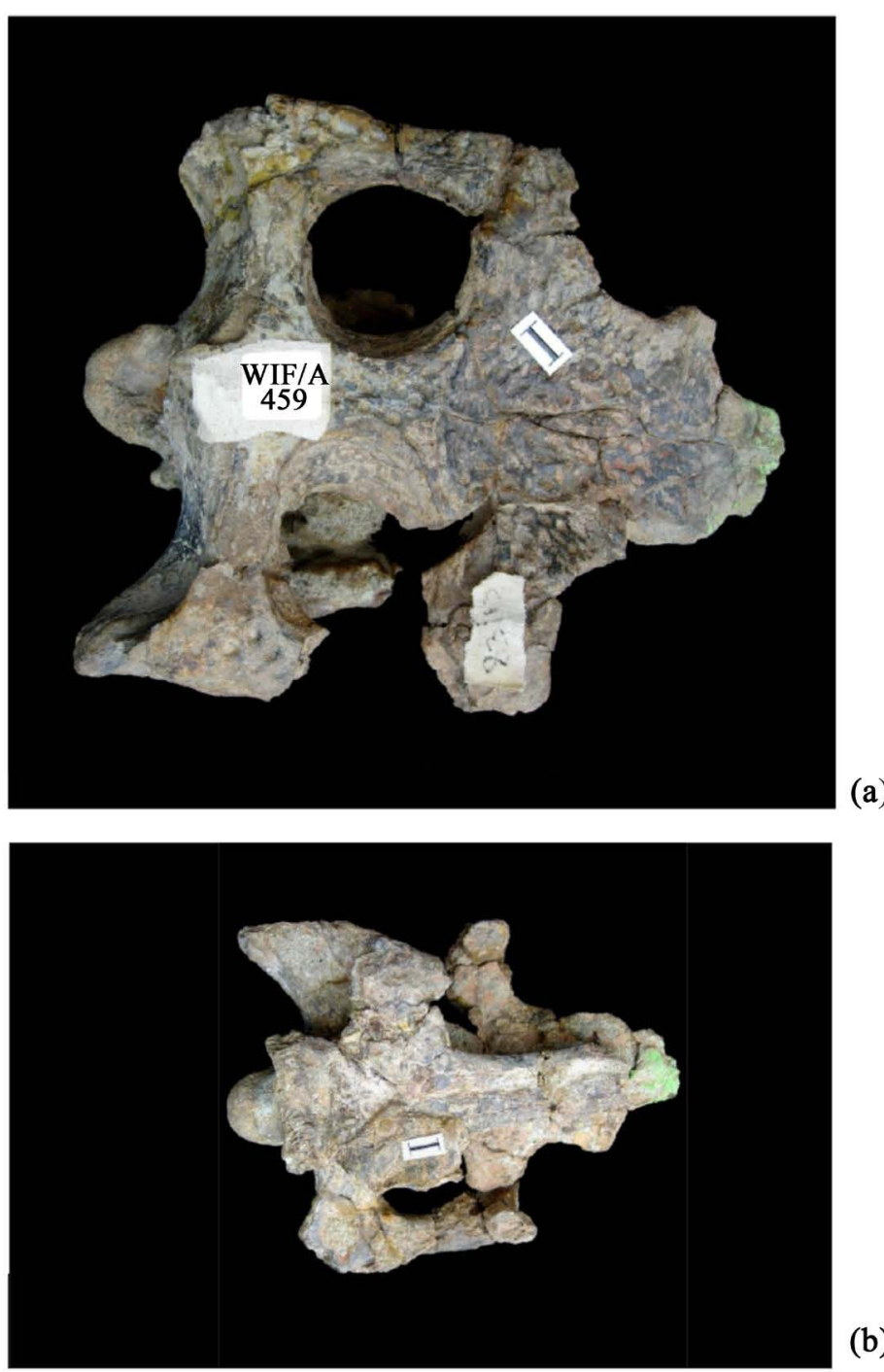

a)

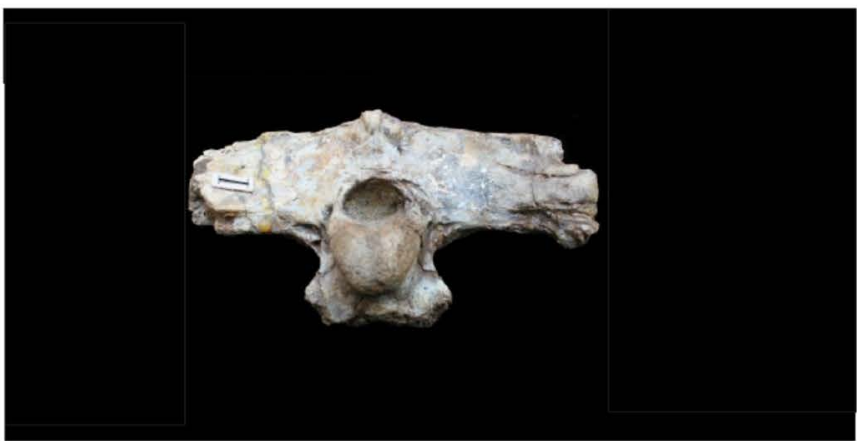

(b)

(c)

Plate 4. Gavialis cf. gangeticus, part of upper cranium (WIF/A 459), (a) Dorsal view; (b) Palatinal view; (c) Occipital view. Bar represents $5 \mathrm{~cm}$.

Material, locality and horizon: WIF/A 458, a part of maxillary (Plate 5(a) \& Plate 5(b)); 2.5 km northeast of Rampur Village (Ambala), Pinjor Formation.

Description: The preserved material belongs to the posterior part of a maxillary. The maximum length of the preserved specimen is approximately $14 \mathrm{~cm}$. On the dorsal side, a median line is distinct with two maxillary bones. The maximum width of the snout is approximately $9.2 \mathrm{~cm}$. On the ventral surface, five alveolies are dis- 
tinct for the right maxillary teeth. The alveolies are almost identical in shape and size; the interdental space ranges between $10-12 \mathrm{~mm}$.

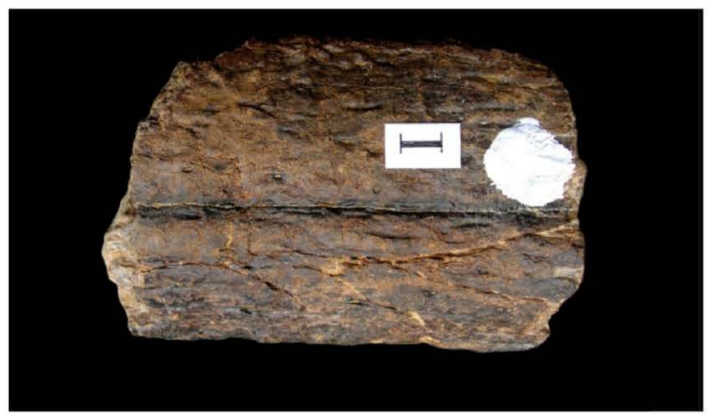

(a)

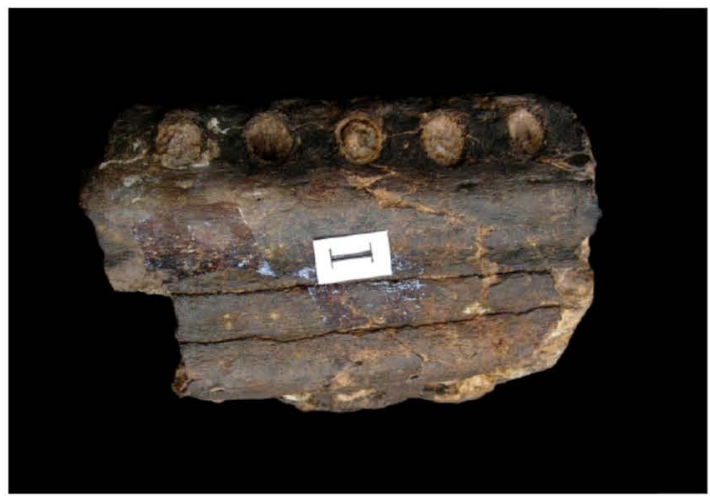

(b)
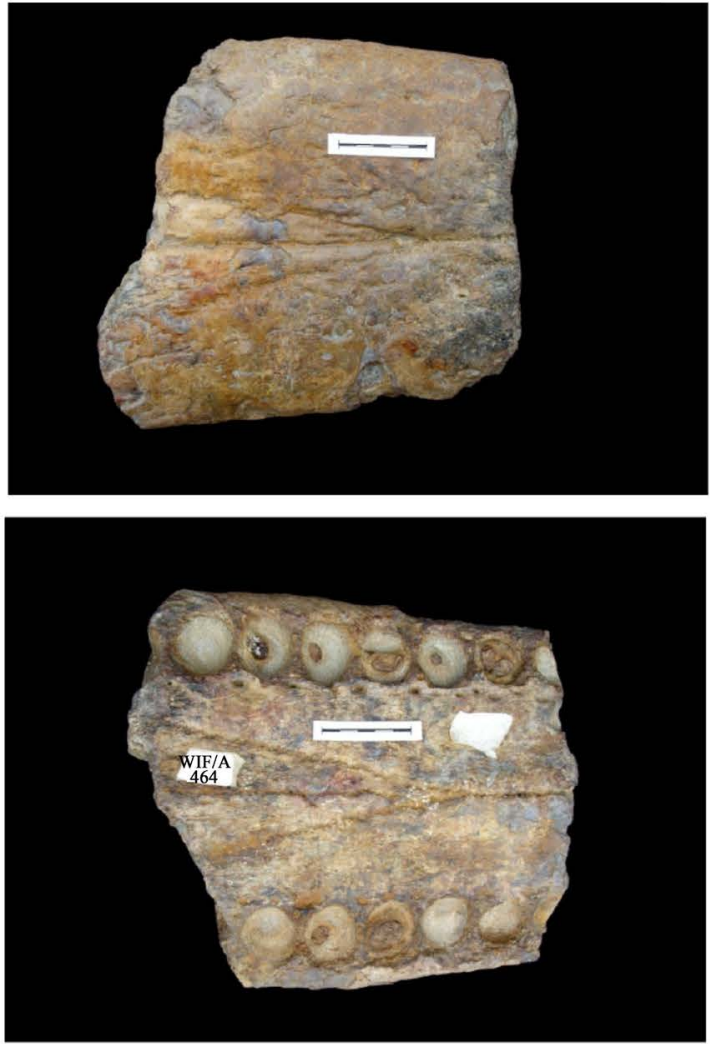

(c)

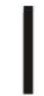

Plate 5. ((a), (b)) Gavialis cf. gangeticus, posterior part of maxillary (WIFA/ 458), (a) Dorsal view, (b) Palatinal view. ((c), (d)) Rhamphosuchus crassidens, maxillary fragment (WIF/A 464), (c) Dorsal view, (d) Palatinal view. Each bar represents 5 cm. Upper bar for ((a), (b)), lower bar for ((c), (d)). 
Genus: Rhamphosuchus Lydekker, 1886

Ramphosuchus crassidens (Falconer and Cautley, 1840)

(Plate 5(c) \& Plate 5(d))

Material, locality and horizon: WIF/A 464, maxillary fragment; $1.75 \mathrm{~km}$ east northeast of Jamni Village (Sirmur), pre-Pinjor beds (Saketi Formation, =Tatrot Formation).

Description: The preserved maxillary fragment bears six alveolies on the right and five alveolies on the left side. The $6^{\text {th }}$ anterior most alveoli of the left maxilla and the $7^{\text {th }}$ anterior most alveoli of the right maxilla are partly seen. These alveolies are very large and indicating by the huge teeth size an extraordinarily giant animal. The alveolies for the teeth attachment are shallow. The maximum length of the preserved specimen is $25.8 \mathrm{~cm}$. The median suture is well marked. The interdental pits are well marked and the interdental spaces range between 2 - $4 \mathrm{~mm}$. The posterior portion of the palatine is broken; the palatine fenestrae are not distinct. On the dorsal surface of the skull, maxillo-nasal sutures are distinctly visible and they join sharply the median line. The size of the teeth and the presence of maxillo-nasal sutures suggests that the specimen belong to the posterior maxillary part of the skull.

Order: Testudines Batsch, 1988

Family: Bataguridae (sensu Gaffney and Meylan, 1988)

Subfamily: Batagurinae Gray, 1870

Batagur sp. (Gray, 1830)

(Plate 6)

Material, locality and horizon: WIF/A 451, terminally broken large turtle shell; 1 km east northeast of Masumpur Village (Ambala), basal part of the Pinjor Formation.

Description: The shell is large, its outline is oval and broken anteriorly as well as posteriorly. The shell is highly elevated and arched. The scute seams and bony sutures are completely reduced on the specimen which indicates that the specimen is a fully grown if not even an individually adult old specimen. The laterals are steeply inclined but the marginals are upturned and are nearly horizontal. This is a characteristic feature not seen in the living Batagur baska. The seam between the marginals is indistinct. Central or lateral keels are absent. As neither shield impressions nor bony sutures are preserved, just the big size and general shape with the absence of keels might be indicative for its generic determination. The specimen is larger than the living Batagur; its straight carapace length is about $93 \mathrm{~cm}$, the width is about $50 \mathrm{~cm}$ and straight height is about $42 \mathrm{~cm}$.

Geoclemys hamiltonii (Gray, 1831)

(Plate 7 \& Plate 8)

Material, locality and horizon: WIF/A 452, shell with partly broken carapace and partial plastron fragment (Plate 7); 2.25 km northeast of Haripur Village (Sirmur), pre-Pinjor beds (=Tatrot Formation).

Description: The preserved part of the carapace exposes following horny shields and according bony plates: cervical, centrals 1-4, laterals 1-4, marginal 1-9, nuchal, neurals 1-6, pleurals 1-6 and peripherals 1-8. The shell is convex; the interrupted central and lateral keels are greatly developed. The cervical is small. The $1^{\text {st }}$ central is narrow anteriorly and broadest posteriorly and is nearly bell shaped. The $2^{\text {nd }}$ central is longer than the $1^{\text {st }}$ and is almost as broad as long. It is sub-hexagonal in shape. The $3^{\text {rd }}$ central is hexagonal in shape and is as broad as long; it is almost equal to the size of the $2^{\text {nd }}$ central. The $4^{\text {th }}$ central is almost as long as the $3^{\text {rd }}$. It is also of hexagonal shape. The nuchal is narrower anteriorly and wider posteriorly; the $1^{\text {st }}$ neural is quadrolateral in shape. The $2^{\text {nd }}-6^{\text {th }}$ neurals are hexagonal and are generally broader than long. The neurals are short-sided anteriorly. The pleurals are generally in the shape of an elongated pentagon; the proximal width of alternate pleurals is narrower than their width. The straight carapace length is about $43 \mathrm{~cm}$ and its width is about $29 \mathrm{~cm}$ at a straight height of about $16 \mathrm{~cm}$. Only a very small portion of the plastron is preserved comprising of both almost complete femorals and a part of the left abdominal shield. The median seam is straight and clearly marked. Due to erosion a large portion of the plastron is lacking.

Material, locality and horizon: WIF/A 454, shell, a partly preserved carapace and anterio-posteriorly broken plastron (Plate 8); 2.5 km northeast of Rampur Village (Ambala), Pinjor Formation.

Description: The carapace consists of laterals 1-3, marginals 4-7; pleurals 2-5, and peripherals 4-7. The proximal termination of the laterals is not present owing to the broken central part. The marginals are nearly rectangular in shape. The proximal termination of the pleurals is lacking due to the broken central part. The carapace is broken from the anterior margin of the $2^{\text {nd }}$ pleural. The $4^{\text {th }}, 5^{\text {th }}$ and $6^{\text {th }}$ peripherals are nearly pentagonal in shape; peripheral 7 is nearly rectangular in shape. The plastron is concave. The preserved part of the plastron 


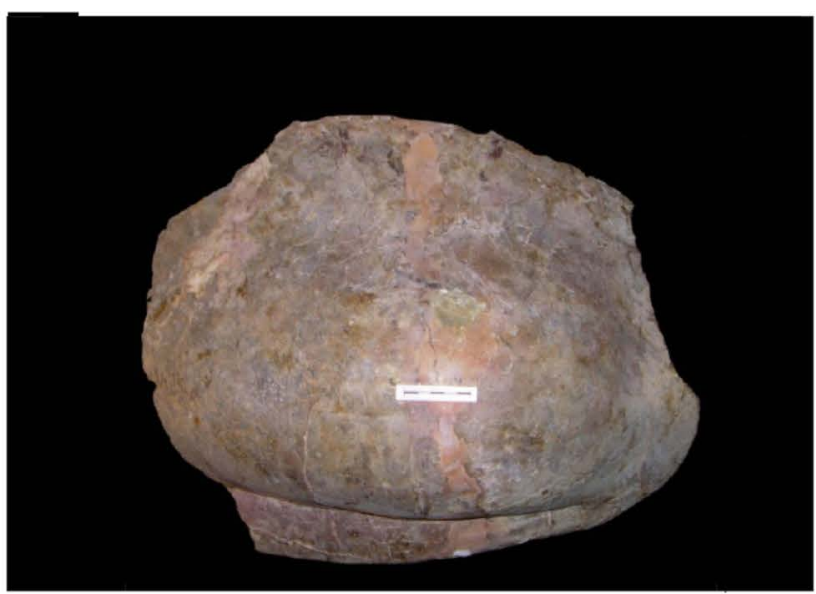

(a)

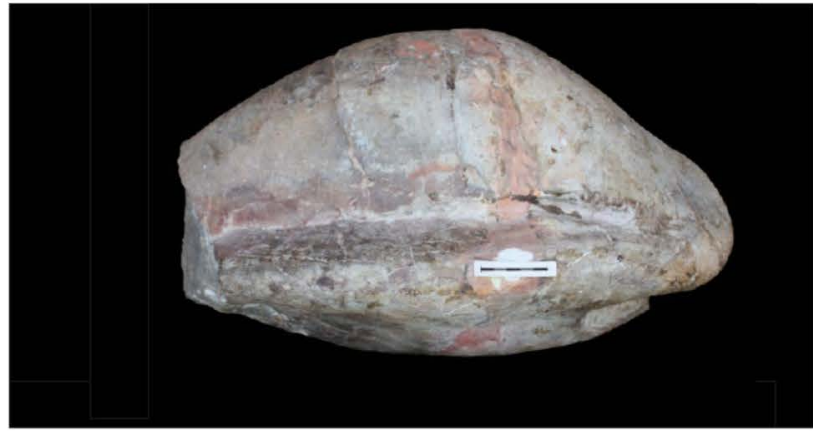

(b)

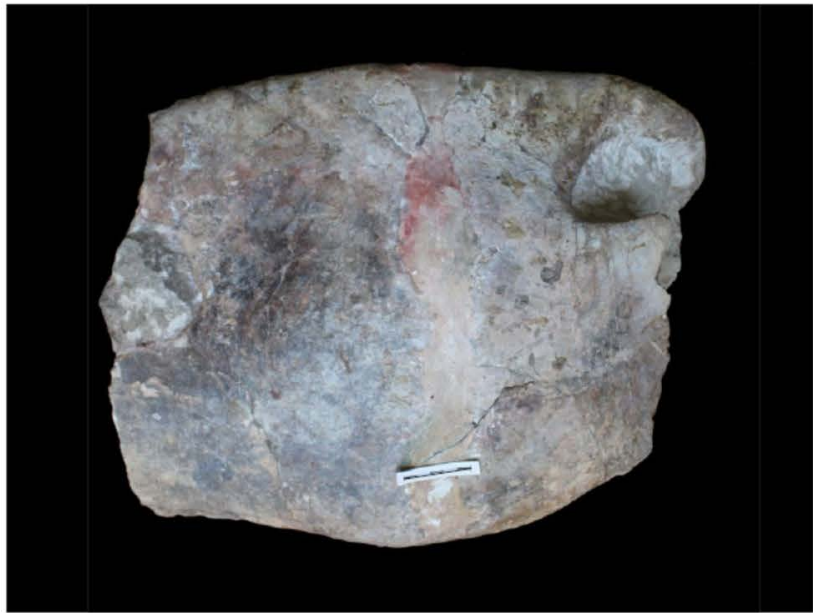

(c)

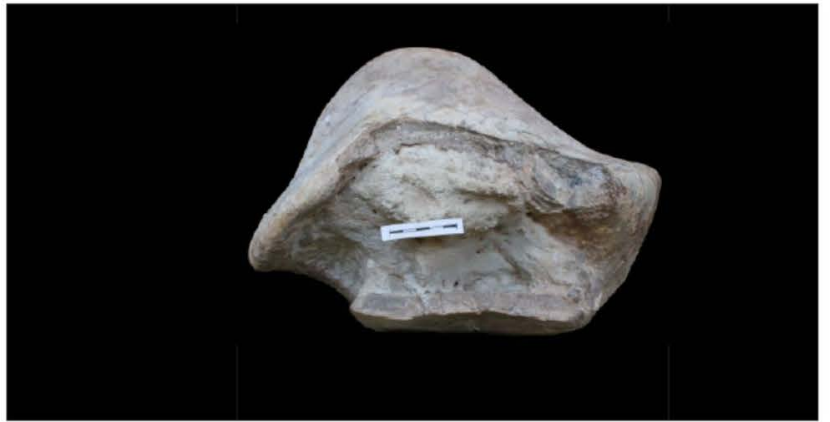

(d)

Plate 6. Batagur sp., turtle shell broken near anterior and posterior margins (WIF/A 451), (a) Dorsal view, (b) Right lateral view, (c) Ventral view, (d) Anterior view. Bar represents $5 \mathrm{~cm}$. 


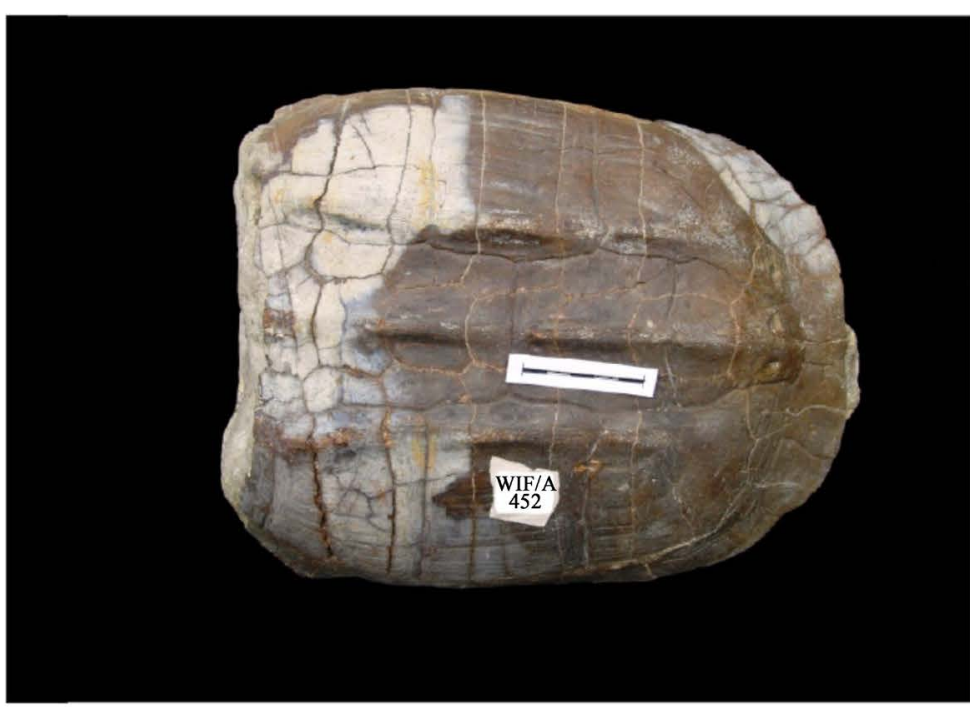

(a)

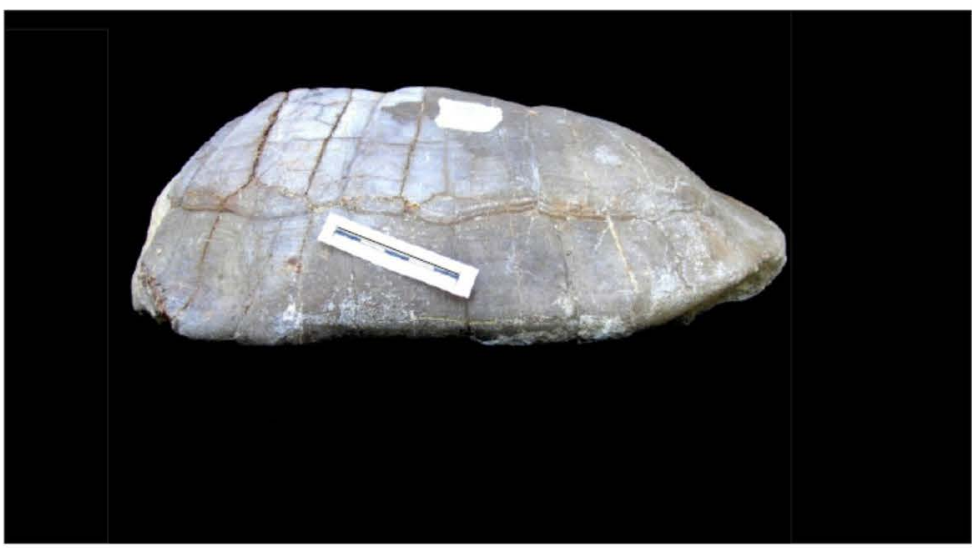

(b)

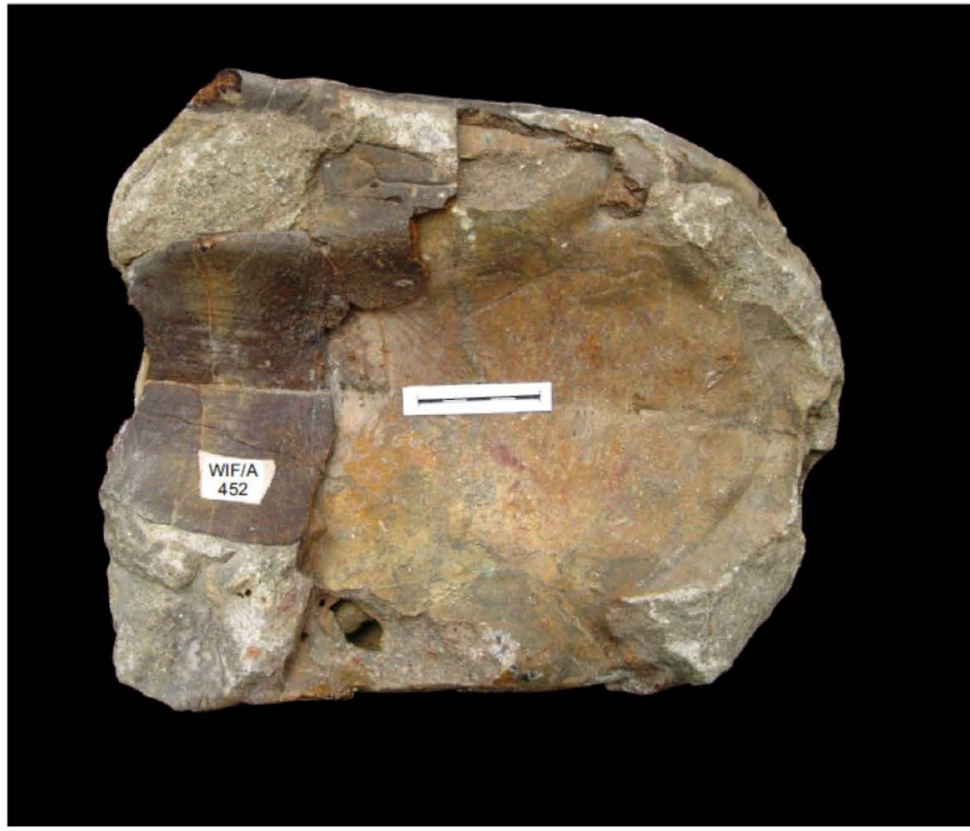

(c)

Plate 7. Geoclemys hamiltoni, shell with partial carapace and plastron (WIF/A 452), (a) Dorsal view, (b) Right lateral view, (c) Ventral view. Bar represents $5 \mathrm{~cm}$. 


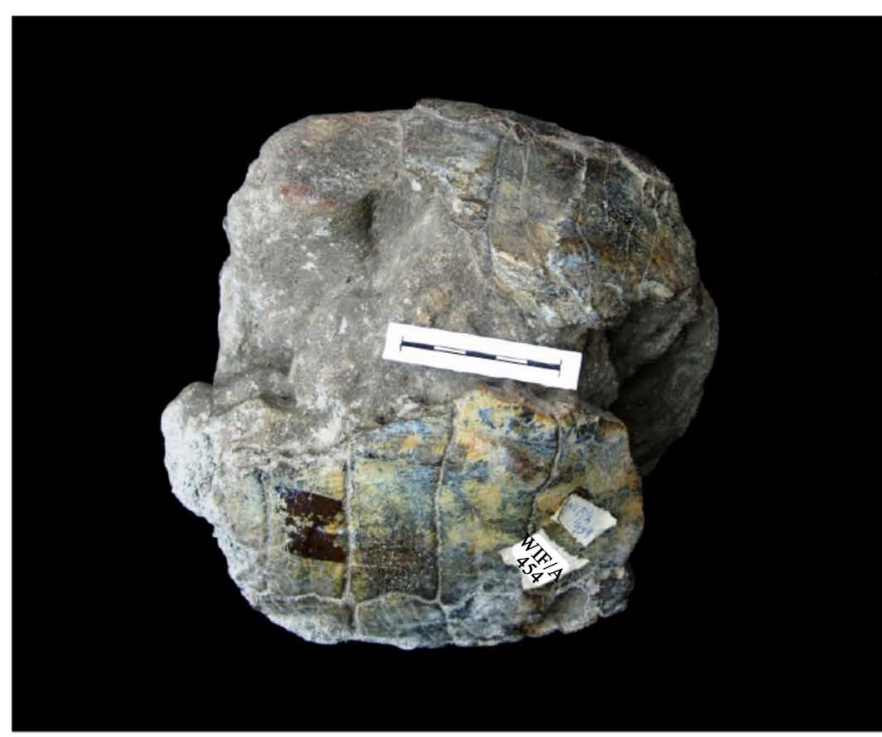

(a)
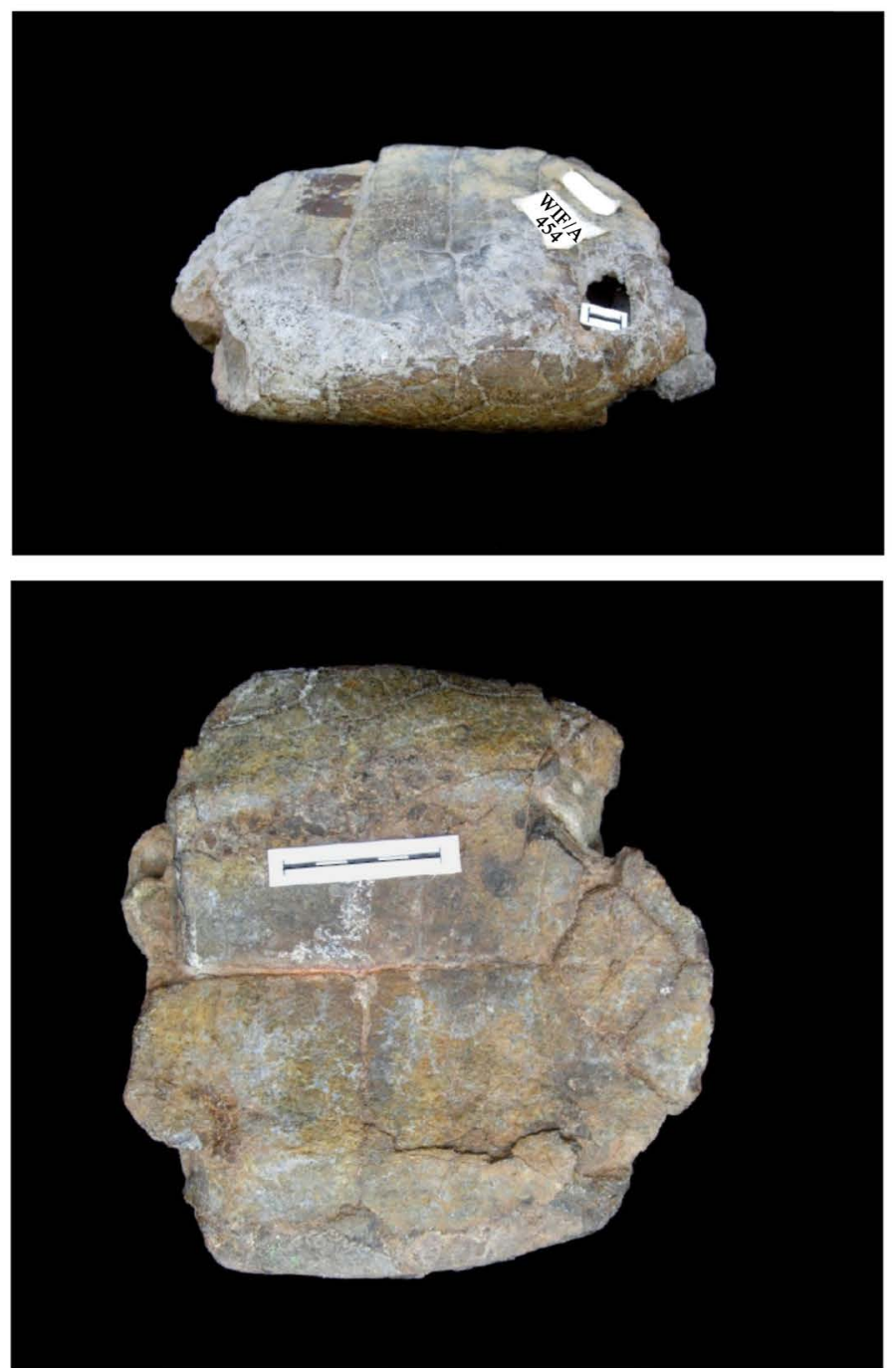

(b)

(c)

Plate 8. Geoclemys hamiltoni, partial shell (WIF/A 454), (a) Dorsal view, (b) Right lateral view, (c) Ventral view. Bar represents $5 \mathrm{~cm}$. 


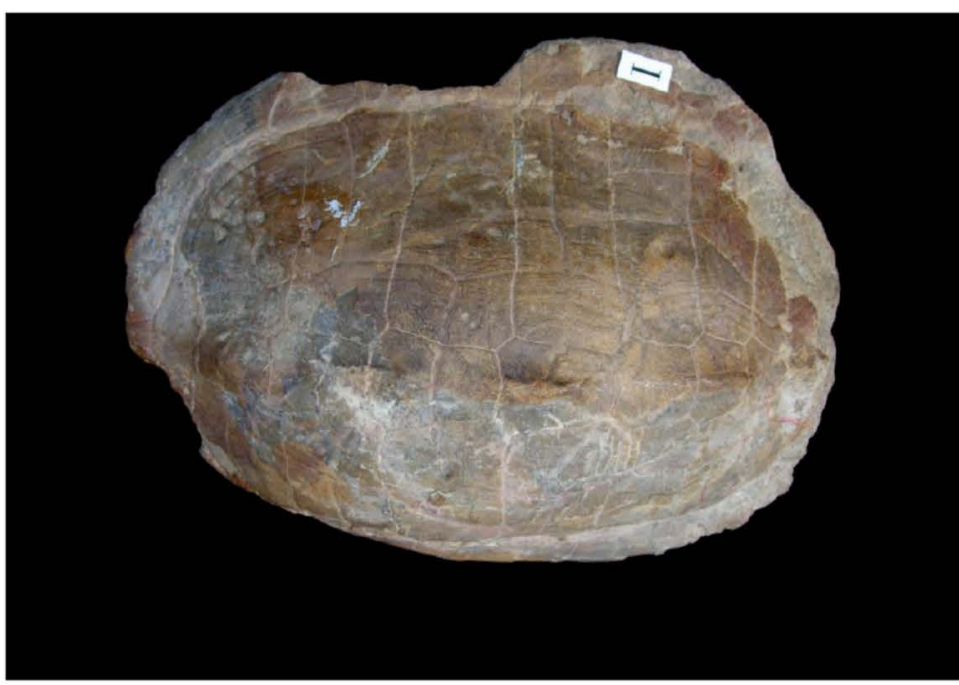

(a)

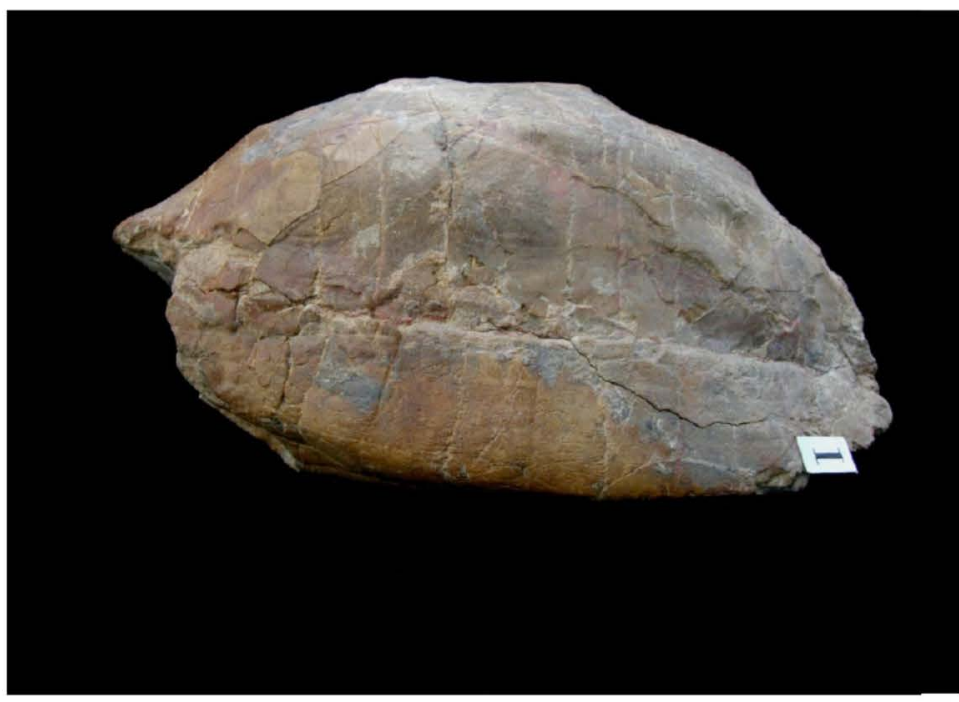

(b)

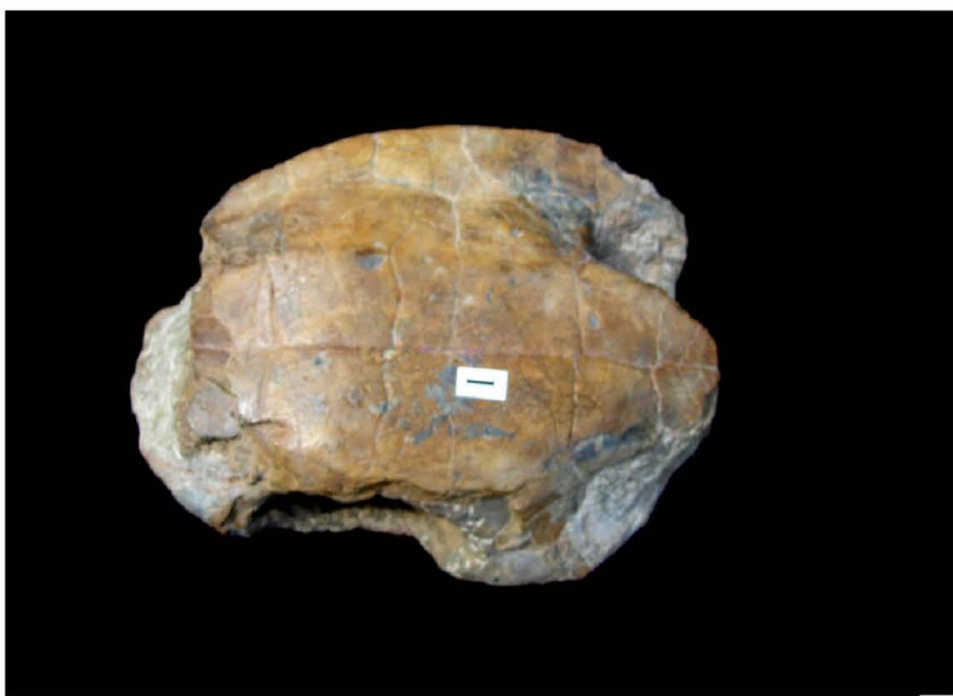

(c)

Plate 9. Hardella cf. thrurjii, complete shell (WIF/A 453), (a) Dorsal view, (b) Left lateral view, (c) Ventral view. Bar represents $5 \mathrm{~cm}$. 
includes: A part of the epiplastron, complete entoplastron, hyoplastron and posteriorly broken hypoplastron; partly preserved humeral, pectoral and abdominal. The plastron is broken from the anterio-lateral margin of the epiplastron and from the seam between the abdominal and femoral shields. The median seam is very prominent. The maximum length of the reconstructed plastron might have measured approximately $30 \mathrm{~cm}$ at a maximum width of approximately $16 \mathrm{~cm}$.

Hardella cf. thurjii (Gray, 1831)

(Plate 9)

Material, locality and horizon: WIF/A 453, complete shell; 1.75 km northeast of Rampur Village (Ambala), pre-Pinjor beds (Saketi Formation, =Tatrot Formation).

Description: The shell is convex, with only one interrupted central keel. The preserved parts of the carapace include following shields and plates: Cervical, centrals 1-5, laterals 1-4, marginals 1-9, neurals 1-7, pleurals 1-6 and peripherals 1-9. The cervical is short; the centrals are either as broad as long or slightly broader than long. The $1^{\text {st }}$ central is very small in comparison to the following centrals. The $1^{\text {st }}$ lateral is rectangular and small. The marginals are also generally rectangular in shape. The nuchal is hexagonal in shape. The $1^{\text {st }}$ neural is rectangular in shape and is longer than broad. The $2^{\text {nd }}-7^{\text {th }}$ neurals are either as broad as long or slightly longer than broad; the neurals are short-sided anteriorly. The posterior neurals after the $6^{\text {th }}$ are not seen due to erosion. The pleurals are generally pentagonal in shape. The peripherals 2 - 8 are nearly rectangular in shape. The peripheral 6 is larger than the neighboring peripherals. The straight carapace length is approximately $32 \mathrm{~cm}$, its width is approximately $25 \mathrm{~cm}$ and the straight height is approximately $17.5 \mathrm{~cm}$. The preserved parts of the almost complete plastron include the anteriorly broken entoplastron, the suture between the right epiplastra and hyoplastra, hyoplastron, hypoplastra, xiphiplastra and as shield imprints the anteriorly incomplete humerals, pectorals, abdominals, femorals and posteriorly incomplete anals. A median suture is clearly distinct. The humero-pectoral seam lies posterior to the entoplastron. The epiplastron has a straight anterior margin. The maximum length of the plastron is $28 \mathrm{~cm}$ and the maximum width is approximately $17 \mathrm{~cm}$.

\section{Palaeoecological Implications}

For the existence of both crocodile taxa (Gavialis, Crocodylus) together with that of the giant Thoracosaur, Rhamphosuchus and big sized emydid turtle one must demand at least similar or even fully tropical conditions than nowadays prevail [30]. Thus, a tropical rainy or monsoon climate must already have existed for PlioPleistocene time. The presence of various species of turtles and crocodiles in the Siwalik suggests an open fresh water environment [13] [31]. The presence of large vertebrate fauna and flora reported so far from the Upper Siwalik [31] demands the presence of an open forested grassland with perennial rivers and swamps providing appropriate feeding conditions for crocodiles [12]. The presence of associated riverine shore areas ranging from pebbly sediments, sand banks and grass banks is the most suitable for many batagurines feeding e.g., on many molluscs, crabs, grass, algae and weeds [14]. These data coincide with palaeoenvironmental conditions drawn from the geological and sedimentological studies [12]. The reptilian fauna is indicative of bank or near bank community having co-existed with the mammalian fauna. The presence of Stegodon, Elephas and Hexaprotodon (fossil hippo) also supports the palaeoecological conditions deducted from the presence of these reptiles.

\section{Acknowledgements}

The first author is thankful to Director, Wadia Institute of Himalayan Geology for the facilities. Thanks are also due to Mr. Gobind Mehra and Dr. D.C. Sati for help in collection of reptile fossils in Haripur area, and to Dr. R. K. Sehgal for discussions. Peter Veital, Rahul Srivastava and A. K. Pandit assisted in moulding and casting of the fossils.

\section{References}

[1] Johnson, N.M., Stix, J., Tauxe, L., Cerveny, P.F. and Tahirkheli, R.A.K. (1985) Paleomagnetic Chronology, Fluvial Processes, and Tectonic Implications of the Siwalik Deposits near Chinji Village, Pakistan. Journal of Geology, 93, 27-40. http://dx.doi.org/10.1086/628917

[2] Ranga Rao, A., Agarwal, R.P., Sharma, U.N., Bhalla, M.S. and Nanda, A.C. (1988) Magnetic Polarity Stratigraphy and Vertebrate Palaeontology of the Upper Siwalik Subgroup of Jammu Hills, India. Journal Geological Society of India, 31, 361-385. 
[3] Cautley, P.T. (1836) Note on the Fossil Crocodile of the Sivàlik Hills. In: Cantley and Hodgson, Eds., Reptiles and Mammals of Indian Sub-Continent, Reprinted from Asiatic Researches, Cosmo Publications, New Delhi, 25-32.

[4] Cautley, P.T. (1836) The Fossil Gharial of the Sivàlik Hills. In: Cantley and Hodgson, Eds., Reptiles and Mammals of Indian Sub-Continent, Reprinted from Asiatic Researches, Cosmo Publications, New Delhi, 32-38.

[5] Lydekker, R. (1885) Siwalik and Narbada Chelonia. Palaeontologia Indica, 3, 154-209.

[6] Lydekker, R. (1886) Siwalik Crocodilia, Lacertilia and Ophidia. Palaeontologia Indica, 3, 210-240.

[7] Lydekker, R. (1886) Catalogue of the Remains of Siwalik Vertebrata Contained in the Geological Department of the Indian Museum Calcutta, (II), Aves, Reptilia and Pisces. Government of India Press, Calcutta, 1-23.

[8] Tewari, B.S. and Badam, G.L. (1969) A New Species of Fossil Turtle from the Upper Siwalik of Pinjore, India. Palaeontology, 12, 555-558.

[9] Steel, R. (1973) Handbuch der Palaeoherpetologie, Part 16: Crocodylia. Gustav Fischer, Stuttgart, 116 p.

[10] Mlynarski, M. (1976) Handbuch der Palaeoherpetologie. Part 7. Testudines. Fischer Verlag, Stuttgart, 130 p.

[11] Badam, G.L. (1979) Pleistocene Fauna of India. Deccan College, Pune, 250 p.

[12] Patnaik, R. and Schleich, H.H. (1993) Fossil Crocodile Remains from the Upper Siwalik of India. Mitt. Bayer. Staatsslg. Paläont. Hist. Geol., 33, 91-117.

[13] Corvinus, G. and Schleich, H.H. (1994) An Upper Siwalik Reptile Fauna from Nepal. Courier Forschungsinstitut Senckenberg, 173, 239-259.

[14] Das, I. (1991) Taxonomic Status of the Pleistocene Turtle Geoclemys sivalensis. Journal of Herpetology, 25, $104-107$. http://dx.doi.org/10.2307/1564804

[15] Sahni, M.R. and Khan, E. (1964) Stratigraphy, Structure and Correlation of the Upper Shivaliks East of Chandigarh. Journal of the Palaeontological Society of India, 4, 61-74.

[16] Sastry, M.V.A., Bhatt, D.K., Dutta, A.K., Verma, B.C., Ranga Rao, A. and Ganju, J.L. (1981) Excursion Guide. Proceeding Field Conference NQ Boundary 1979, IGCP 41, Chandigarh, 223-241.

[17] Azzaroli, A. and Napoleone, G. (1982) Magneto Stratigraphic Investigation of the Upper Sivaliks near Pinjor, India. The Rivista Italiana di Paleontologia e Stratigrafia, 87, 739-762.

[18] Nanda, A.C. (1981) Occurrence of the Pre-Pinjor Beds in the Vicinity of Chandigarh. In: Sastry, M.V.A., Kurien, T.K., Dutta, A.K. and Biswas, S., Eds., Field Conference Neogene/Quaternary Boundary, India, 1979, Proceedings Geological Survey of India, 113-116.

[19] Nanda, A.C. (1994) Upper Siwalik Mammalian Faunas from Chandigarh and Jammu Regions with Comments on Certain Faunal Discrepancies. In: Ahmed, A. and Sheikh, A.M., Eds., Geology in South Asia—I, Hydrocarbon Institute of Pakistan, Islamabad, 39-45.

[20] Verma, B.C. (1989) Search for Microvertebrates in the Upper Siwalik of Markanda Valley, Sirmur District, Himachal Pradesh and Development of Upper Siwalik Biostratigraphy. Records of the Geological Survey of India, 122, 309-312.

[21] Nanda, A.C. (2002) Upper Siwalik Mammalian Faunas of India and Associated Events. Journal of Asian Earth Sciences, 21, 47-58. http://dx.doi.org/10.1016/S1367-9120(02)00013-5

[22] Nanda, A.C. (2015) Siwalik Mammalian Faunas of the Himalayan Foothills with Reference to Biochronology, Linkages and Migration. Publication of Wadia Institute of Himalayan Geology, Monograph Series No. 2, 341 p.

[23] Pilgrim, G.E. (1932) The Fossil Carnivora of India. Palaeontologia Indica, 18, 232 p.

[24] Pilgrim, G.E. (1938) Are the Equidae Reliable for the Correlation of the Siwalik with the Coenozoic Stages of North America? Records of the Geological Survey of India, 73, 437-482.

[25] Sangode, S.J., Kumar, R. and Ghosh, S.K. (1996) Magnetic Polarity Stratigraphy of the Siwalik Sequence of Haripur Area (H.P.), NW Himalaya. Journal of the Geological Society of India, 47, 683-704.

[26] Cande, S.C. and Kent, D.V. (1995) Revised Calibration of the Geomagnetic Polarity Timescale for the Late Cretaceous and Cenozoic. Journal of Geophysical Research, 100, 6093-6095. http://dx.doi.org/10.1029/94JB03098

[27] Nanda, A.C. (2008) Comments on the Pinjor Mammalian Fauna of the Siwalik Group in Relation to the Post-Siwalik Faunas of Peninsular India and Indo-Gangetic Plain. Quaternary International, 192, 6-13. http://dx.doi.org/10.1016/j.quaint.2007.06.022

[28] Nanda, A.C., Sati, D.C. and Mehra, G. (1991) Preliminary Report on the Stratigraphy and Mammalian Faunas of the Middle and Upper Siwalik, West of River Yamuna, Paonta, Himachal Pradesh. Journal of Himalayan Geology, 2, 151158.

[29] Nanda, A.C. (1997) Some Biostratigraphic Observations Based on the Upper Siwalik Faunas of the Siwalik Group of India and Nepal. In: Wijayananda, N.P., Cooray, P.G. and Mosley, P., Eds., Geology in South Asia—II, Geological 
Survey \& Mines Bureau, Dehiwala, 171-189.

[30] Maskey, T.M. and Schleich, H.H. (1992) Untersuchungen und Schutzmaßnahmen zum Gangesgavial in Südnepal. Natur und Museum, 122, 258-267.

[31] Patnaik, R. (1991) Micropalaeontology, Biostratigraphy and Palaeoenvironmental Analysis of the Siwalik Sequences in the Saketi-Nahan Area (H.P.). Ph.D. Thesis, Panjab University, Chandigarh.

[32] Ranga Rao, A., Nanda, A.C., Sharma, U.N. and Bhalla, M.S. (1995) Magnetic Polarity Stratigraphy of the Pinjor Formation (Upper Siwalik) near Pinjore, Haryana. Current Science, 68, 1231-1236.

[33] Kumaravel, V., Sangode, S.J., Kumar, R. and Siddaiah, N.S. (2005) Magnetic Polarity Stratigraphy of Plio-Pleistocene Pinjor Formation (Type Locality), Siwalik Group, NW Himalaya, India. Current Science, 88, 1453-1461.

\section{Submit or recommend next manuscript to SCIRP and we will provide best service for you:}

Accepting pre-submission inquiries through Email, Facebook, LinkedIn, Twitter, etc. A wide selection of journals (inclusive of 9 subjects, more than 200 journals)

Providing 24-hour high-quality service

User-friendly online submission system

Fair and swift peer-review system

Efficient typesetting and proofreading procedure

Display of the result of downloads and visits, as well as the number of cited articles

Maximum dissemination of your research work

Submit your manuscript at: http://papersubmission.scirp.org/ 